Article

\title{
Application of Polymer Inclusion Membranes Doped with Alkylimidazole to Separation of Silver and Zinc Ions from Model Solutions and after Battery Leaching
}

\author{
Elzbieta Radzyminska-Lenarcik ${ }^{1, *(D)}$, Malgorzata Ulewicz ${ }^{2}$ D and Ilona Pyszka $^{1}$ \\ 1 Faculty of Chemical Technology and Engineering, UTP University of Science and Technology, \\ Seminaryjna 3 Street, PL 85-326 Bydgoszcz, Poland; ilona.pyszka@utp.edu.pl \\ 2 Faculty of Civil Engineering, Czestochowa University of Technology, Dabrowskiego 69 Street, \\ PL 42-201 Czestochowa, Poland; malgorzata.ulewicz@pcz.pl \\ * Correspondence: elaradz@utp.edu.pl; Tel.: +48-52-374-9065
}

Received: 2 June 2020; Accepted: 9 July 2020; Published: 11 July 2020

check for updates

\begin{abstract}
New materials, such as polymer inclusion membranes, can be used for water and wastewater treatment. In this paper, the selective transport of silver(I) and zinc(II) ions from nitrate solutions through the polymer inclusion membranes (PIMs), which consist of cellulose triacetate as a polymeric support, $o$-nitrophenyl pentyl ether as a plasticizer, and either 1-hexylimidazole (1) or 1-hexyl-2-methylimidazole (2) as an ion carrier, is studied. Both $\mathrm{Zn}(\mathrm{II})$ and $\mathrm{Ag}(\mathrm{I})$ model solutions $\left(\mathrm{C}_{\mathrm{M}}\right.$ $=0.001 \mathrm{M}, \mathrm{pH}=6.5)$, as well as the solutions after the leaching of a spent battery with a silver-zinc cell (silver-oxide battery), are tested. The results show that $\mathrm{Zn}(\mathrm{II})$ ions are effectively transported through PIMs containing either carrier, whereas $\mathrm{Ag}(\mathrm{I})$ is more easily transported through PIMs doped with (1). In the case of the leaching solution after $24 \mathrm{~h}$ transport, the recovery coefficients of $\mathrm{Ag}(\mathrm{I})$ and $\mathrm{Zn}(\mathrm{II})$ for PIMs doped with (1) are 86\% and 90\%, respectively, and for PIMs doped with (2), 47\% and $94 \%$, respectively. The influence of basicity and structure of carrier molecules on transport kinetics is discussed as well. PIMs are characterized by using an atomic force microscopy (AFM) technique.
\end{abstract}

Keywords: polymer inclusion membrane; separation ions; silver; zinc; alkylimidazole

\section{Introduction}

The world's silver reserves are estimated at approximately 540,000 Mg. Annually, approximately $22,000 \mathrm{Mg}$ of this metal is extracted from ore. These data show that in approximately 25 years, silver reserves may be depleted. Therefore, the recovery of silver from various silver-containing waste materials, such as printed circuit boards, electronic devices, catalysts, and silver-zinc batteries, is necessary. Over the last 10 years, average annual silver recovery has constituted only $6600 \mathrm{Mg}$ of silver, which is approximately $22 \%$ of the annual supply of this raw material [1]. This level varies greatly from country to country. For instance, in Sweden, Boliden produces approximately $150 \mathrm{Mg}$ of silver from electronic waste (25\% of its production) annually, whereas in the USA in 2015, only $21 \mathrm{Mg}$ out of every $186 \mathrm{Mg}$ of consumed silver was recycled, i.e., approximately $11 \%$. The processing of waste materials is important as the largest producers obtain only $252 \mathrm{~g}$ of silver on average from $1 \mathrm{Mg}$ of ore, and Boliden obtains $1 \mathrm{~kg}$ of silver on average from $1 \mathrm{Mg}$ of waste mobile phones. Unfortunately, not all waste materials containing silver, including silver-zinc batteries, containing approximately $31 \%$ silver, are used efficiently. Annually, 1.5 billion silver-zinc batteries are produced, consuming almost $550 \mathrm{Mg}$ of silver alone. Silver-zinc battery life does not exceed two years, so batteries become waste relatively quickly, and they need to be recycled for the recovery of silver. The level of recycling for this type of material is low. For instance, in Canada, only 2.2\% of waste $\mathrm{Zn}-\mathrm{Ag}$ batteries are recycled [2]. Therefore, effective waste management technologies are still being sought for this waste [3-5]. 
A number of reports on the recovery of silver from waste solutions (wastewater) containing silver can be found in the literature. Electrochemical methods [6], electro-flotation process [7], ion flotation [8,9], ion exchange [10], silica gel sorption on activated organosulfur compounds [11], chitosan-based hydrogel sorption [12], or adsorption [13,14] can be used to recover silver. Zinc can be also effectively recovered from waste materials by hydrometallurgical processes [15-21]. In hydrometallurgical processes, solid waste-containing metals, including silver and zinc, are comminuted and then leached [22,23]. For leaching silver, nitric acid is most commonly used [24]. Additionally, attempts were made to leach waste with thiourea and its derivatives [25]. The solutions obtained as a result of leaching are subjected to separation processes, which may include separation with liquid membranes [26-34]. Various carriers are used in membrane processes, e.g., thiourea derivatives [26,27], phosphoric acid derivatives [28,29], calixpyrroles [30,31], crown ethers [32-36] or calixarene [37]. Currently, polymer membranes are the most popular for membrane processes, which are increasingly used in the separation of various metal ions [38-40].

1-alkylimidazole (alkyl—from hexyl to decyl) were used for $\mathrm{Cu}$ separation from a $\mathrm{Cu}-\mathrm{Zn}-\mathrm{Co}-\mathrm{Ni}$ mixture from nitrate [41,42] or chloride solutions [43], and for $\mathrm{Zn}$ separation from $\mathrm{Zn}-\mathrm{Co}-\mathrm{Ni}$ [44], $\mathrm{Zn}-\mathrm{Cd}-\mathrm{Ni}$ [45], and $\mathrm{Zn}-\mathrm{Mn}$ mixtures [46]. 1-vinylimidazole was used to separate $\mathrm{Cu}$ (II) and $\mathrm{Fe}(\mathrm{III})$ ions during transport across polyvinyl acetate membranes [47]. 1-alkyl-2-methylimidazole (alkyl—from hexyl to octyl, and decyl) was used for $\mathrm{Cu}$ separation from a $\mathrm{Cu}-\mathrm{Zn}-\mathrm{Co}-\mathrm{Ni}$ mixture [42,48-50], as well for Zn separation from a Zn-Cd-Ni mixture [45]. Separation of Zn from a Zn-Cd [51] or a Zn-Mn [45] mixture is also possible using alkyl imidazole derivatives.

The aim of this study was to examine the possibility of separation and recovery of silver(I) and zinc(II) from solutions after leaching of waste silver-zinc batteries in the process of transport through polymer inclusion membranes (PIMs). Alkyl imidazole derivatives of different structure, i.e., 1-hexylimidazole and 1-hexyl-2-methylimidazole, were used as ion carriers.

\section{Materials and Methods}

\subsection{Reagents}

The inorganic chemicals, i.e., silver(I) and zinc(II) nitrates, $65 \% \mathrm{HNO}_{3}$ solution, and tetramethylammonium hydroxide were of analytical grade and were purchased from POCh (Gliwice, Poland). The organic reagents, i.e., cellulose triacetate (CTA), o-nitrophenyl pentyl ether (o-NPPE), and dichloromethane were also of analytical grade, were purchased from Fluka (Busch, Switzerland), and were used without further purification. The 1-hexylimidazole (1) and 1-hexyl-2-methylimidazole (2) pictured in Figure 1 were synthesized according to the procedure described in [52].

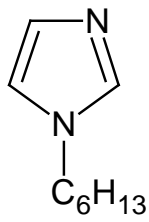

(a)

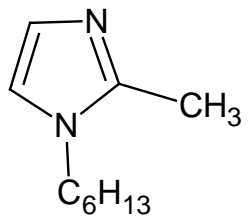

(b)

Figure 1. The chemical formula of 1-alkyl-imidazoles (carriers): (a) 1-hexylimidazole (1) b.p. 134-136 ${ }^{\circ} \mathrm{C} / 12 \mathrm{mmHg}$; (b) 1-hexyl-2-methylimidazole (2) b.p. $130-131^{\circ} \mathrm{C} / 14 \mathrm{mmHg}$.

The possibility of the separation of zinc and silver was tested from model solutions containing $0.001 \mathrm{~mol} / \mathrm{dm}^{3}$ of the tested metal ions. Model solutions of each metal ion were prepared by dissolving appropriate amounts of nitrates in deionized water. All aqueous solutions were prepared using analytical reagent-grade chemicals and deionized water (conductivity $=0.10 \mu \mathrm{S} / \mathrm{cm}$ ). Silver and zinc 
contents were determined using an atomic absorption spectroscopy (AAS) method (AAS Spectrometer, Solaar 939, Unicam, Geleen, Netherlands).

The spent silver-oxide $\left(\mathrm{Zn}-\mathrm{Ag}_{2} \mathrm{O}\right)$ button cells (Figure 2) were obtained from a local market (watchmaking workshops). After mechanical comminution, the silver-oxide button cells (containing $10 \%$ zinc, $31 \%$ silver, $0.5 \%$ mercury, and other materials) were leached for $6 \mathrm{~h}$ with $2 \mathrm{~mol} / \mathrm{dm}^{3}$ of $\mathrm{HNO}_{3}$ solution at a temperature of $70{ }^{\circ} \mathrm{C}$. Under these conditions, $87.1 \%$ silver and $95.0 \%$ zinc were leached from the powder. The leached solution was then boiled with a small amount of activated carbon to remove any organic material. The obtained solution was filtered, and the levels of silver and zinc were determined using the AAS method. The $\mathrm{Zn}(\mathrm{II})$ and $\mathrm{Ag}(\mathrm{I})$ content was $9.5 \%$ and $27 \%$, respectively. For transport tests, the solution was diluted.

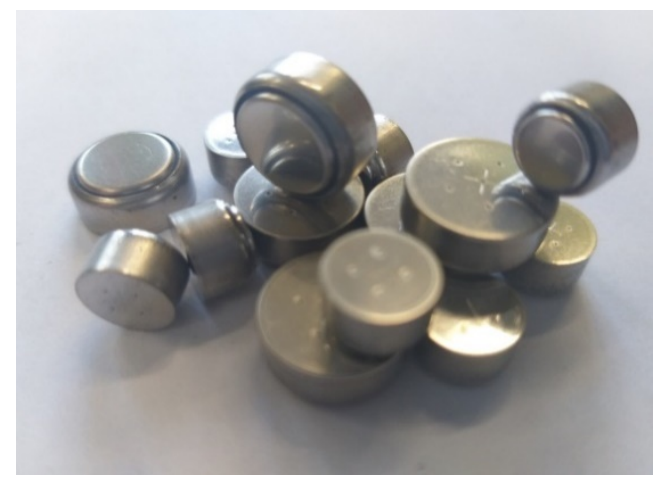

(a)

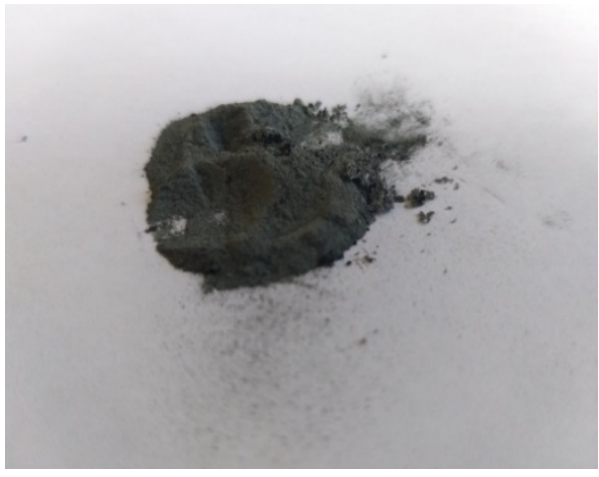

(b)

Figure 2. The button cell batteries (a) and used battery powder (b).

\subsection{Polymer Inclusion Membrane}

The polymer inclusion membranes were obtained and prepared for metal ion transport according to the procedure described in previous studies $[21,41,46,48-50,53]$. The composition of the membranes and their thicknesses are given in Table 1.

Table 1. The composition of the membrane used.

\begin{tabular}{ccc}
\hline Support & Plasticizer & Carrier \\
\hline $\begin{array}{c}\text { cellulose triacetate } \\
\text { (CTA) }\end{array}$ & $\begin{array}{c}o \text {-nitrophenyl pentyl ether } \\
(o-\mathrm{NPPE})\end{array}$ & $\begin{array}{c}\text { 1-hexylimidazole (1) or } \\
\text { 1-hexyl-2-methylimidazole (2) }\end{array}$ \\
\hline $\begin{array}{l}\text { Quantitative composition: } \\
2.6 \mathrm{~cm}^{3} o \text {-NPPE } / 1 \mathrm{~g} \text { CTA and } 1.0 \mathrm{~mol} / \mathrm{dm}^{3} \text { carriers (calculated on plasticizer) }\end{array}$ \\
Thickness: $28-31 \mu \mathrm{m}$ (standard deviation below 1\%) \\
\hline
\end{tabular}

\subsection{Transport Studies}

Transport experiments were carried out at the temperature of $20 \pm 0.2^{\circ} \mathrm{C}$, according to the procedure described in previous papers $[41,43,46,48-50,53,54]$. The feed and receiving aqueous phases were an aqueous solution with $\mathrm{pH}=6.5$ (tetramethylammonium hydroxide) and $0.01 \mathrm{M} \mathrm{HNO}_{3}$, respectively. Changes in metal concentration in both phases were measured at appropriate time intervals.

\section{Results}

\subsection{Characteristic of Membranes}

Surface PIM characterization was performed by atomic force microscopy (AFM) [21,41,43,46,53-55]. An AFM image of the PIMs doped with (1) or (2) in two- and three-dimensional forms is shown in Figure 3. 


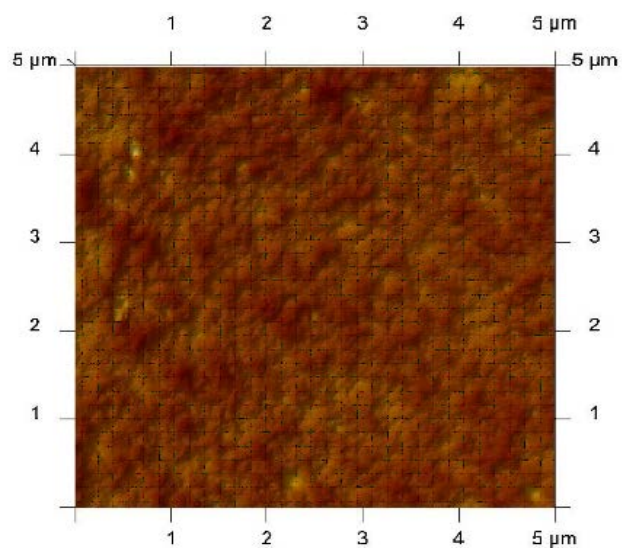

(a)

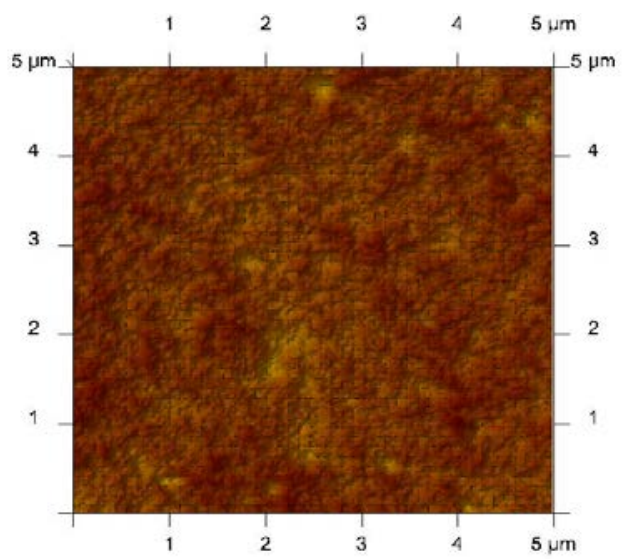

(c)

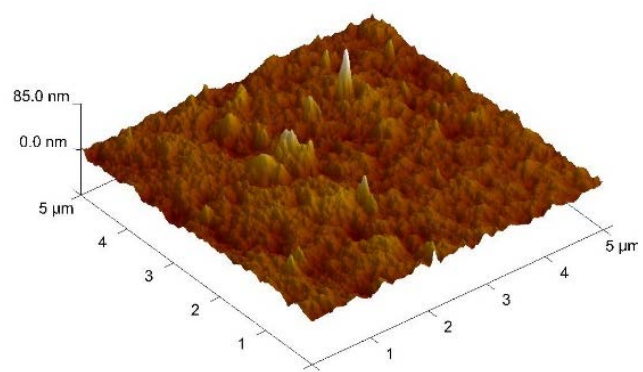

(b)

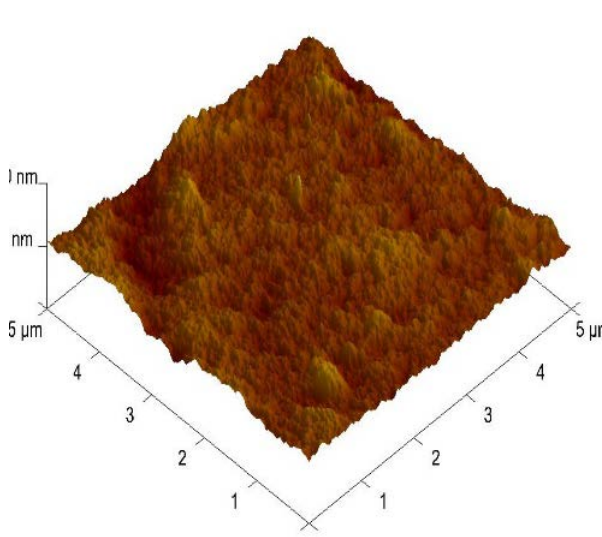

(d)

Figure 3. Atomic force microscopy (AFM) images (2D and 3D) of polymer inclusion membranes (PIMs) with alkylimidazol. (a,b) 1-hexylimidazole (1), (c,d) 1-hexyl-2-methylimidazole (2).

The darker areas in the AFM images (Figure 3) show elongated pores (cavity channels), which may indicate the crystallization of carrier molecules inside the CTA. The same effect was observed by Gherrou et al. [32].

Based on the membrane surface analysis (NanoScope v. 5.12 program, Park Systems Europe $\mathrm{GmbH}$, Mannheim, Germany), the roughness $\left(\mathrm{R}_{\mathrm{q}}, \mathrm{nm}\right)$ and the porosity $(\varepsilon,[\%])$ were determined, which are shown in Table 2 with the tortuosity $(\tau)$, determined from the dependence $(\tau=1-\ln \varepsilon)$, as developed by Wolf and Strieder [56].

Table 2. AFM characterization parameters for PIM doped with 1-alkyl-imidazole.

\begin{tabular}{cccc}
\hline $\begin{array}{c}\text { Carrier in the CTA-o-NPPE } \\
\text { Membrane }\end{array}$ & Effective Pore Size, $\boldsymbol{\mu m}$ & Tortuosity & Roughness $\left(\mathbf{R}_{\mathbf{q}}\right), \mathbf{n m}$ \\
\hline 1-hexylimidazole (1) & $0.050 \pm 0.002$ & 2.34 & $5.70 \pm 0.05$ \\
1-hexyl-2-methylimidazole (2) & $0.053 \pm 0.002$ & 2.37 & $6.20 \pm 0.05$ \\
\hline
\end{tabular}

The roughness, the effective size of pores, and the tortuosity have higher values for membranes containing (2) as the carrier. The roughness of the obtained membranes was lower than the roughness of the CTA membrane obtained by Tor et al., which was $14 \mathrm{~nm}$ [57]. The microstructure of the membrane (roughness [42,57,58], porosity [32,59], and tortuosity [56]) has an impact on the transport. 


\subsection{Transport of $\mathrm{Zn}(I I)$ and $A g(I)$ Ions across PIMs from $\mathrm{Zn}-A g$ Model Solution}

Danesi [60] described the kinetics of transport via PIMs as a first-order process in relation to the metal ion concentration. Based on analytical data, the values of the permeability coefficient $(\mathrm{P})$, initial flux $\left(J_{o}\right)$, selectivity coefficient $(\mathrm{S})$, and recovery coefficient (RF) were calculated on the basis of relationships described in our earlier works [21,46]. All values given are mean values of three replicates with a standard deviation of $5 \%$.

The transport of $\mathrm{Zn}(\mathrm{II})$ and $\mathrm{Ag}(\mathrm{I})$ ions from equimolar nitrate solutions $(\mathrm{pH}=6.5)$ through PIMs doped with (1) or (2) is discussed below. Two-component $\mathrm{Zn}-\mathrm{Ag}$ model solutions containing metal ions at a concentration of $0.001 \mathrm{~mol} / \mathrm{dm}^{3}$ were prepared for this study. The changes in $\mathrm{Ag}$ (I) and $\mathrm{Zn}$ (II) ions concentration during transport are presented in Figure 4.

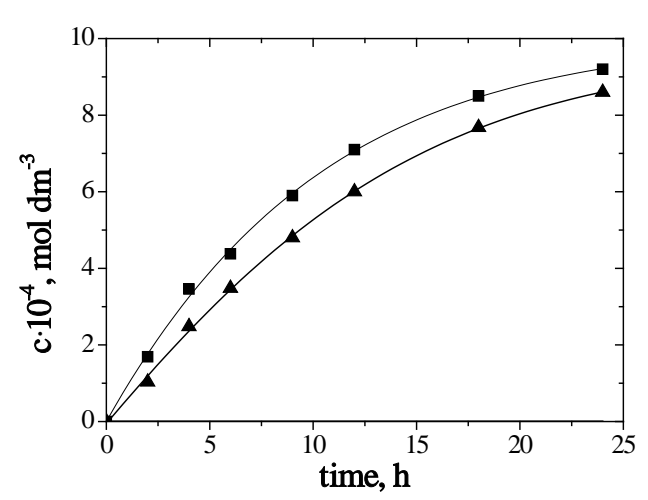

(a)

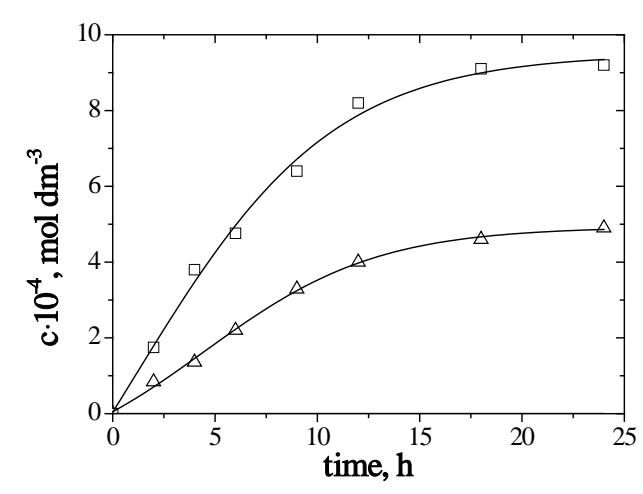

(b)

Figure 4. The changes of $\mathrm{Zn}(\mathrm{II})(\mathbf{\square}, \square)$ and $\operatorname{Ag}(\mathrm{I})(\boldsymbol{\Lambda}, \Delta)$ ions concentration over time during transport

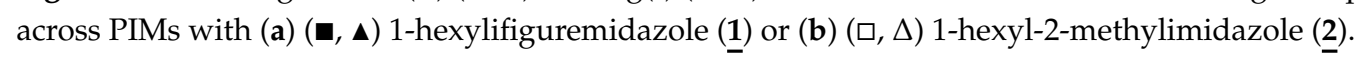

To calculate the value of the rate constant $(k)$ for each membrane, relationships $\ln \left(c / c_{0}\right)=\mathrm{f}(\mathrm{t})$ were plotted (Figure 5).

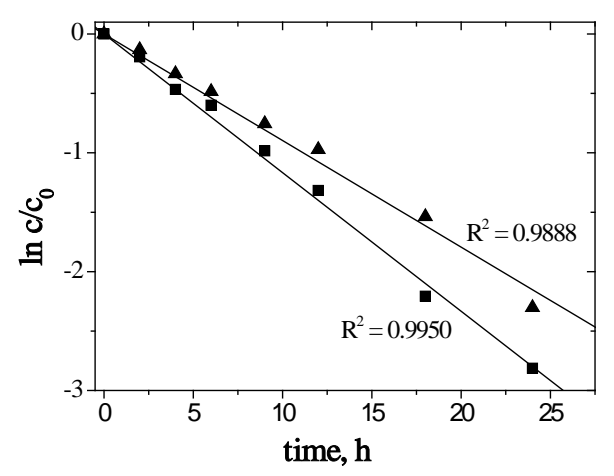

(a)

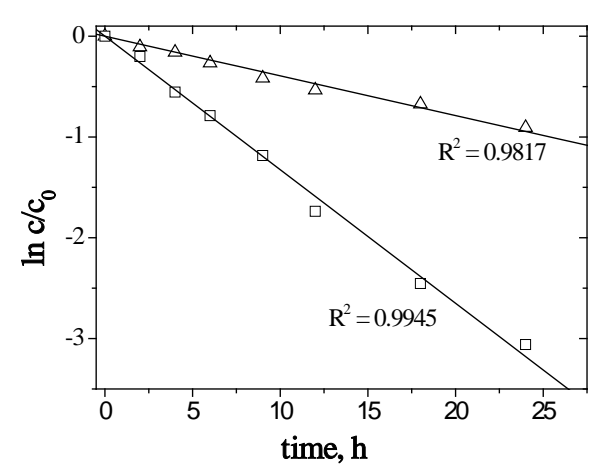

(b)

Figure 5. The relation of $\ln \left(c / c_{o}\right)$ versus time for $\operatorname{Zn}(\mathrm{II})(\boldsymbol{\square}, \square)$ and $\operatorname{Ag}(\mathrm{I})(\boldsymbol{\Delta}, \Delta)$ transport across PIMs with $(\mathbf{a})(\mathbf{\square}, \mathbf{\Lambda})$ 1-hexylimidazole (1) or (b) $(\square, \Delta)$ 1-hexyl-2-methylimidazole (2).

In the case of the tested membranes, the functions $\ln \left(c / c_{0}\right)=\mathrm{f}(\mathrm{t})$ are rectilinear (the correlation coefficient $\left(R^{2}\right)$ ranging from 0.9817 to 0.9950$)$, which confirms Danesi's transport model [60]. The transport rate of metal ions decreased in the following order: $\mathrm{Zn}(\mathrm{II})>\mathrm{Ag}(\mathrm{I})$, and though the transport rates of $\mathrm{Zn}(\mathrm{II})$ and $\mathrm{Ag}(\mathrm{I})$ ions through PIMs with (1) are similar, $\mathrm{Ag}(\mathrm{I})$ ions are much more slowly transported through PIMs doped with (2). 
The values of parameters characterizing transport (initial flux values $\left(J_{0}\right)$ and selectivity coefficients $\left.\mathrm{S}_{\mathrm{Zn}(\mathrm{II}) / \mathrm{Ag}(\mathrm{I})}\right)$ are shown in Table 3.

Table 3. The values of parameters characterizing $\mathrm{Zn}(\mathrm{II})$ and $\mathrm{Ag}(\mathrm{I})$ transport across PIM doped with alkylimidazole; membrane: $\mathrm{pH}$ of the feed phase was 6.5, receiving phase was $0.01 \mathrm{M} \mathrm{HNO}_{3}$.

\begin{tabular}{|c|c|c|c|}
\hline Carrier & Metal Ions & $\begin{array}{c}\text { Initial Flux } J_{0}, \\
\mu \mathrm{mol} / \mathrm{m}^{2} \cdot \mathrm{s}\end{array}$ & $\begin{array}{c}\text { Selectivity Coefficients } \\
\mathrm{S}_{\mathrm{Zn}(\mathrm{II}) / \mathrm{Ag}(\mathrm{I})}\end{array}$ \\
\hline \multirow{2}{*}{$\underline{1}$} & $\mathrm{Zn}(\mathrm{II})$ & 2.02 & $\mathrm{Zn}(\mathrm{II})>\operatorname{Ag}(\mathrm{I})$ \\
\hline & $\operatorname{Ag}(\mathrm{I})$ & 1.46 & 1.38 \\
\hline \multirow{2}{*}{$\underline{2}$} & $\mathrm{Zn}(\mathrm{II})$ & 2.09 & $\mathrm{Zn}(\mathrm{II})>\operatorname{Ag}(\mathrm{I})$ \\
\hline & $\operatorname{Ag}(\mathrm{I})$ & 0.48 & 4.35 \\
\hline
\end{tabular}

As indicated by the data shown in Table 3, for all investigated PIMs, the initial flux value for the transport of $\mathrm{Zn}(\mathrm{II})$ ions is higher than for $\mathrm{Ag}(\mathrm{I})$ ions and achieves the highest value for (2). In the case of a PIM doped with (1), both ions are transported and the $\mathrm{Zn}(\mathrm{II}) / \mathrm{Ag}(\mathrm{I})$ selectivity coefficient (S) has a lower value than (2), for which the coefficient is above four.

The literature [61-64] shows that the size and position of the alkyl group in alkylimidazole molecules affects both their acid-base and complex-forming properties. The stability constant values of $\mathrm{Zn}(\mathrm{II})$ and $\mathrm{Ag}(\mathrm{I})$ [62-64] complexes with the investigated carriers are summarized in Table 4.

Table 4. The dissociation constants $\left(\mathrm{pK}_{\mathrm{a}}\right)$ of 1-hexylimidazole (1) and 1-hexyl-2-methylimidazole (2) and the stability constants $(\log \beta)$ their complexes with $\mathrm{Zn}(\mathrm{II})$ and $\mathrm{Ag}(\mathrm{I})$ ions.

\begin{tabular}{cccc}
\hline Carrier & $\mathrm{pK}_{\mathrm{a}}$ [56] & Metal Ions & $\log \boldsymbol{\beta}$ \\
\hline$\underline{\mathbf{1}}$ & \multirow{2}{*}{7.30} & $\mathrm{Zn}(\mathrm{II})$ & $5.87[62]$ \\
$\underline{\mathbf{2}}$ & \multirow{2}{*}{8.32} & $\mathrm{Zn}(\mathrm{I})$ & $6.33[63]$ \\
& & $\mathrm{Ag}(\mathrm{I})$ & $5.80[64]$ \\
\hline
\end{tabular}

Table 4 shows that the basicity of (2) is an order of magnitude higher than the basicity of 1-hexylimidazole (1). Complexes with $\mathrm{Zn}(\overline{\mathrm{II}})$ ions have similar stability for (1) and (2). The stability of $\mathrm{Ag}(\mathrm{I})$ complexes is an order of magnitude higher for (2) than for (1). These highly complex-forming properties enable the use of (1) and (2) as effective carriers in PIM transport processes, and the difference in the stability of complexes forming in the membrane can be the basis for the separation of $\mathrm{Ag}(\mathrm{I})$ and $\mathrm{Zn}(\mathrm{II})$ ions.

The initial fluxes of $\mathrm{Zn}(\mathrm{II})$ ions are comparable in both carriers (Table 3), whereas the initial flux value for $\mathrm{Ag}(\mathrm{I})$ is much higher for (1) than for (2). The $\mathrm{Zn} / \mathrm{Ag}$ selectivity coefficient (S) for (2) is much higher than for (1). The reason for this difference is the steric effect, resulting from the presence of a methyl substituent at position 2 in (2) (Figure 1). It hinders the formation of complexes with ions of many metals $[46,49,53,54]$, and with $\mathrm{Ag}(\mathrm{I})$ ions in particular. The impact of the steric effect depends on the structure of the metal ion coordination sphere. In the case of zinc ions, tetrahedral complexes are formed next to octahedral complexes, facilitating the transport of $\mathrm{Zn}$ (II) ions through the membrane $[46,49,53,54]$. A similar phenomenon was observed in the case of $\mathrm{Zn}$ (II) separation from $\mathrm{Zn}-\mathrm{Cd}-\mathrm{Co}-\mathrm{Ni}$ mixtures [65], Zn-Cd mixtures [51], Zn-Cd-Ni mixtures [45], and Zn-Mn mixtures [46], as well as zinc recovery from metallurgical waste [66] or galvanic wastewater [53].

\subsection{Recovery of Metal}

The recovery coefficients $(R F)$ of $\mathrm{Zn}(\mathrm{II})$ and $\mathrm{Ag}(\mathrm{I})$ ions as a result of transport by PIMs doped with (1) or (2) from their equimolar nitrate solutions into $\mathrm{HNO}_{3}$ solutions are shown in Table 5. 
Table 5. The recovery coefficients $(R F)$ of $\mathrm{Zn}(\mathrm{II})$ and $\mathrm{Ag}(\mathrm{I})$ ions from feed phase after $24 \mathrm{~h}$ transport across PIMs doped 1-hexylimidazole (1) or 1-hexyl-2-methylimidazole (2); conditions as in Table 2.

\begin{tabular}{ccc}
\hline Carrier & Metal Ions & RF, $\%$ \\
\hline$\underline{\mathbf{1}}$ & $\operatorname{Zn}(\mathrm{II})$ & 92 \\
$\mathbf{2}$ & $\operatorname{Ag}(\mathrm{I})$ & 90 \\
$\underline{\mathrm{Zn}}$ & $\mathrm{Ag}(\mathrm{II})$ & 94 \\
& 51 \\
\hline
\end{tabular}

In the case of (1), high and comparable recovery coefficients were obtained after $24 \mathrm{~h}$ transport, whereas in the case of (2), zinc recovery was very high (94\%), but only $51 \%$ of the silver was recovered.

\subsection{Transport of Zn(II) and $A g(I)$ Ions across PIMs from the $A g-Z n$ Battery Leaching Solution}

The next step was the separation of $\mathrm{Zn}-\mathrm{Ag}$ from the solution after leaching a battery with a silver-zinc cell. The concentration of silver(I) and zinc(II) ions in the solution was $0.003 \mathrm{~mol} / \mathrm{dm}^{3}$ and $0.015 \mathrm{~mol} / \mathrm{dm}^{3}$, respectively. In Figure 6, kinetic curves for transport of $\mathrm{Ag}(\mathrm{I})$ and $\mathrm{Zn}(\mathrm{II})$ ions from solutions after leaching the $\mathrm{Zn}-\mathrm{Ag}_{2} \mathrm{O}$ battery are shown.

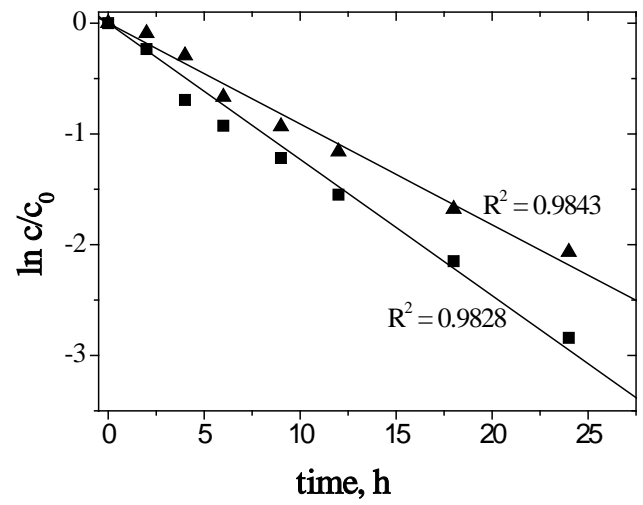

(a)

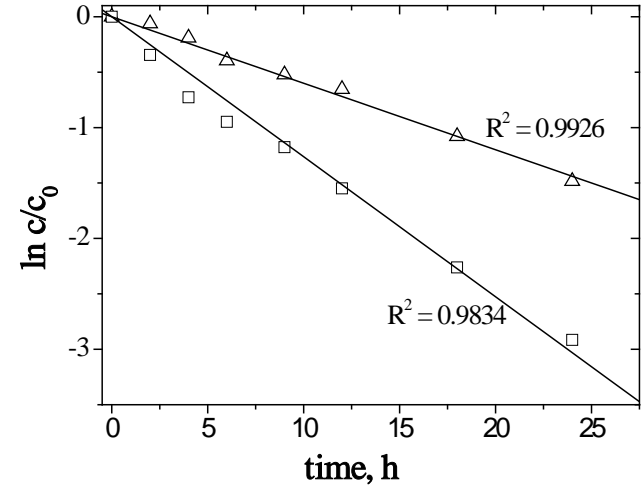

(b)

Figure 6. The relation of $\ln \left(c / c_{o}\right)$ versus time from the leaching solution for $\operatorname{Zn}(\mathrm{II})(\mathbf{\square}, \square)$ and $\operatorname{Ag}(\mathrm{I})(\boldsymbol{\Lambda}, \Delta)$



Figure 6 shows that $\ln \left(c / c_{0}\right)$ dependencies as a function of time are linear. Hence, the transport of $\mathrm{Ag}(\mathrm{I})$ and $\mathrm{Zn}(\mathrm{II})$ ions through PIMs using (1) or (2), according to the model given by Danesi [60], can be described by the first-order kinetics in terms of the transported ions. The values of initial fluxes for the transport of metal ions from the solution after leaching waste batteries, a selectivity coefficient, and a degree of separation are shown in Table 6.

Table 6. Initial fluxes $\left(J_{0}\right)$, selectivity coefficients (S), and recovery coefficients $(R F)$ of $\mathrm{Zn}(\mathrm{II})$ and $\mathrm{Ag}(\mathrm{I})$ ions from feed phase after $24 \mathrm{~h}$ transport across PIMs doped with 1-hexylimidazole (1) or 1-hexyl-2-methylimidazole (2); feed phase: the leaching solution $(\mathrm{pH}=6.5)$, receiving phase: $0.01 \mathrm{M} \mathrm{HNO}_{3}$.

\begin{tabular}{ccccc}
\hline Carrier & Metal Ions & $\boldsymbol{J}_{\mathbf{0}}, \boldsymbol{\mu \mathbf { m o l }} / \mathbf{m}^{\mathbf{2}} \cdot \mathbf{s}$ & $\mathbf{S}_{\mathbf{Z n}(\mathrm{II}) / \mathbf{A g}(\mathrm{I})}$ & $\mathbf{R F}, \boldsymbol{\%}$ \\
\hline$\underline{\mathbf{1}}$ & $\mathrm{Zn}(\mathrm{II})$ & 3.67 & & 90 \\
$\mathbf{2}$ & $\mathrm{Ag}(\mathrm{I})$ & 3.24 & & 86 \\
$\underline{\mathbf{Z n}}$ & $\mathrm{Zn}(\mathrm{II})$ & 3.98 & 3.46 & 94 \\
\hline
\end{tabular}


The initial flux, shown in Table 6, for Ag(I) ion transport through the polymer membranes containing (1) was higher than in the case of membranes containing (2). The initial flux for $\mathrm{Zn}$ (II) ion transport through the polymer membranes containing (2) was higher than in the case of membranes containing (1). The partition coefficients of $\mathrm{Zn}(\mathrm{II}) / \mathrm{Ag}(\overline{\mathrm{I}})$ ions, using (1) or (2), were 1.13 and 3.46, respectively. The high recovery of zinc(II) $(90 \%)$ and silver(I) $(86 \%)$ was obtained as a result of the transport through membrane with (1). In the case of membrane with (2), the recovery of zinc(II) and silver(I) were $94 \%$ and $47 \%$, respectively.

Comparing the data from Tables 5 and 6, it can be concluded that the results obtained for model and true solutions are comparable.

\section{Conclusions}

The polymer inclusion membranes can be used due to their properties and long-term stability for water and wastewater treatment. The use of these polymer membranes containing 1-hexylimidazole (1) or 1-hexyl-2-methylimidazole (2) allows the separation of $\mathrm{Ag}(\mathrm{I})$ and $\mathrm{Zn}(\mathrm{II})$ ions in the transport process from both model and real solutions. In the case of PIMs with (1) , both ions were transported and the $\mathrm{Zn}(\mathrm{II}) / \mathrm{Ag}(\mathrm{I})$ selectivity coefficient was not high. In the case of PIMs with (2), Zn(II) ions were transported better than $\mathrm{Ag}(\mathrm{I})$ ions, so the selectivity coefficient was above four. In the case of PIMs doped with (1), the recovery of both ions was high, both in the model solution and in the solution after leaching silver-oxide waste batteries. For PIMs doped with (2), the recovery of $\mathrm{Zn}$ (II) was almost double that of $\mathrm{Ag}(\mathrm{I})$, both in the model and real solutions. To separate $\mathrm{Zn}$ (II) and $\mathrm{Ag}(\mathrm{I})$ using a membrane technique, a two-stage process should be used: firstly, $\mathrm{Zn}$ (II) should be recovered using PIMs doped with (2); secondly, PIMs doped with (1) should be used to recover Ag(I).

Author Contributions: E.R.-L.-Conceptualization. M.U. prepared the membranes, performed and analyzed the transport studies. I.P. and E.R.-L. analyzed the date of SEM and AFM images of membranes. I.P. created figures and collected data in tables. I.P. and M.U. wrote introduction. E.R.-L. and M.U. discussed the results and conclusions. All authors have read and agreed to the published version of the manuscript.

Funding: The financial support of the Ministry of Science and Higher Education Republic of Poland (BN 10/2019) is gratefully acknowledged.

Conflicts of Interest: The authors declare no conflict of interest.

\section{References}

1. Financial Newspaper. Recycled Silver. Available online: http://archiwum.gf24.pl/srebro-z-odzysku (accessed on 3 February 2015).

2. Gold Market. Recycled Silver. Available online: https:/goldenmark.com/pl/mysaver/0214-srebro-odzysku/ (accessed on 8 January 2015).

3. Aktas, S. Silver recovery from spent silver oxide button cells. Hydrometallurgy 2010, 104, 106-111. [CrossRef]

4. Sathaiyan, N.; Nandakumar, V.; Ramachandran, P. Hydrometallurgical recovery of silver from waste silver oxide button cells. J. Power Sources 2006, 161, 1463-1468. [CrossRef]

5. Gamiño-Arroyo, Z.; Tapia-Cisneros, A.; Zamacona-Saucedo, O.M.; Cano-Rodríguez, I.; Aguilera-Alvarado, A.F.; Sánchez-Cadena, L.E.; Gómez-Castro, F.I. Silver recovery from spent silver oxide button cell by liquid-liquid extraction. J. Chem. Eng. Mater. Sci. 2015, 3, 148-153. [CrossRef]

6. Olutoye, M.A.; Alhamdu, J.A. Electrochemical separation of metal silver from industrial wastewater. Adv. Chem. Eng. Sci. 2014, 4, 49896-49900. [CrossRef]

7. Selim, K.A.; El Hosiny, F.I.; Abdel Khalek, M.A.; Osama, I. Kinetics and thermodynamics of some heavy metals removal from industrial effluents through electro-flotation process. Colloids Surf. Sci. 2017, 2, 47-53.

8. Polat, H.; Erdogan, D. Heavy metal removal from waste waters by ion flotation. J. Hazard. Mat. 2007, 148, 267-273. [CrossRef]

9. Charewicz, W.A.; Holowiecka, B.A.; Walkowiak, W. Selective flotation of zinc(II) and silver(I) ions from dilute aqueous solutions. Sep. Sci. Technol. 1999, 34, 2447-2460. [CrossRef] 
10. Singh, R.P.; Pambid, E.R. Selective separation of silver from waste solutions on chromium(III) hexacyanoferrate(III) ion exchanger. Analyst 1990, 115, 301-304. [CrossRef]

11. Akhond, M.; Absalan, G.; Sheikhian, L.; Eskandari, M.M.; Sharghi, H. Di (n-propyl) thiuram disulfide bonded on silica gel as a new sorbent for separation, preconcentration, and measurement of silver ion from aqueous samples. Sep. Purif. Technol. 2006, 52, 53-59. [CrossRef]

12. Song, X.; Li, C.; Xu, R.; Wang, K. Molecular-Ion-Imprinted Chitosan Hydrogels for the Selective Adsorption of Silver(I) in Aqueous Solution. Eng. Chem. Res. 2012, 51, 11261-11265. [CrossRef]

13. Hou, H.; Yu, D.; Hu, G. Preparation and properties of ion-imprinted hollow particles for the selective adsorption of silver ions. Langmuir 2015, 1, 1376-1384. [CrossRef] [PubMed]

14. Liu, X.; Yang, L.; Luo, X.; Pei, J.; Xi, Y.; Liu, C.; Liu, L. A novel non-imprinted adsorbent with superior selectivity towards high-performance capture of $\mathrm{Ag}(\mathrm{I})$. Chem. Eng. J. 2018, 348, 224-231. [CrossRef]

15. Jha, M.K.; Kumar, V.; Singh, R.J. Review of hydrometallurgical recovery of zinc from industrial wastes. Resour. Conserv. Recy. 2001, 33,1-22. [CrossRef]

16. Winiarska, K.; Klimkiewicz, R.; Tylus, W.; Sobianowska-Turek, A.; Winiarski, J.; Szczygiel, B.; Szczygiel, I. Study of the catalytic activity and surface properties of manganese-zinc ferrite prepared from used batteries. J. Chem. 2019, 2019, 5430904. [CrossRef]

17. Sobianowska-Turek, A.; Szczepaniak, W.; Maciejewski, P.; Gawlik-Kobylińska, M. Recovery of zinc and manganese, and other metals ( $\mathrm{Fe}, \mathrm{Cu}, \mathrm{Ni}, \mathrm{Co}, \mathrm{Cd}, \mathrm{Cr}, \mathrm{Na}, \mathrm{K}$ ) from $\mathrm{Zn}-\mathrm{MnO}_{2}$ and $\mathrm{Zn}-\mathrm{C}$ waste batteries: Hydroxyl and carbonate co-precipitation from solution after reducing acidic leaching with use of oxalic acid. J. Power Sources 2016, 325, 220-228. [CrossRef]

18. Chang, L.; Cao, Y.; Fan, G.; Li, C.; Peng, W. A review of the applications of ion floatation: Wastewater treatment, mineral beneficiation and hydrometallurgy. RSC Adv. 2019, 35, 20226. [CrossRef]

19. Sobianowska-Turek, A.; Ulewicz, M.; Sobianowska, K. Ion flotation and solvent sublation of zinc(II) and manganese(II) in the presence of proton-ionizable lariat ethers. Physicochem. Probl. Miner. Process. 2016, 52, 1048-1060. [CrossRef]

20. Ulewicz, M.; Walkowiak, W.; Jang, Y.; Kim, J.S.; Bartsch, R.A. Ion flotation of cadmium(II) and zinc(II) in the presence of proton-ionizable lariat ethers. Anal. Chem. 2003, 75, 2276-2279. [CrossRef]

21. Radzyminska-Lenarcik, E.; Pyszka, I.; Ulewicz, M. Separation of Zn(II), Cr(III), and Ni(II) ions using the polymer inclusion membranes containing acetylacetone derivative as the carrier. Membranes 2020, 10, 88. [CrossRef]

22. Zhang, Y.; Liu, S.; Xie, H.; Zen, X.; Li, J. Current status on leaching precious metals from waste printed circuit noards. Procedia Environ. Sci. 2012, 16, 560-568. [CrossRef]

23. Li, J.H.; Li, X.H.; Zhang, Y.H.; Hu, Q.; Wang, Z.; Fu, F. Study of spent battery material leaching process. Trans. Nonferr. Metal Soc. 2009, 19, 751-755. [CrossRef]

24. Sun, P.P.; Rho, B.J.; Cho, S.Y. Recovery of silver from the nitrate leaching solution of a spent $\mathrm{Ag} / \alpha-\mathrm{Al}_{2} \mathrm{O}_{3}$ catalyst by solvent extraction and reduction. Mater. Trans. 2017, 58, 829-833. [CrossRef]

25. Li, J.-Y.; Xu, X.-L.; Liu, W.-Q. Thiourea leaching gold and silver from the printed circuit boards of waste mobile phones. Waste Manag. 2012, 32, 1209-1212. [CrossRef]

26. Nezhadali, A.; Es'haghi Bahar, Z.S.; Banaei, A.; Shiran, J.A. Selective separation of silver(I) ion through a bulk liquid membrane containing 1,1'-(1,3-Phenylene)bis(3-allylthiourea) as carrier. J. Braz. Chem. Soc. 2016, 27, 99-108. [CrossRef]

27. Mitiche, L.; Khaldoun, I.A.; Tingry, S.; Sahmoune, A. Bulk liquid membrane extraction of silver(I) with 2-mercaptobenzothiazole as a carrier. Kinetic approach. Desalin. Water Treat. 2016, 57, 18710-18717. [CrossRef]

28. Othman, N.; Mat, H.; Goto, M. Separation of silver from photographic wastes by emulsion liquid membrane system. J. Membr. Sci. 2006, 282, 171-177. [CrossRef]

29. Bromberg, L.; Lewin, I.; Warshawsky, A. Membrane extraction of silver by di(2-ethylhexyl) dithiophosphoric acid. J. Membr. Sci. 1992, 70, 31-39. [CrossRef]

30. Amiri, A.A.; Safavi, A.; Hasaninejad, A.R.; Shrghi, H.; Shamsipur, M. Highly selective transport of silver ion through a supported liquid membrane using calix[4]pyrroles as suitable ion carriers. J. Membr. Sci. 2008, 325, 295-300. [CrossRef]

31. Nowik-Zajac, A.; Zawierucha, I.; Kozlowski, C. Selective removal of silver(I) using polymer inclusion membranes containing calixpyrroles. RSC Adv. 2019, 9, 31122-31132. [CrossRef] 
32. Gherrou, A.; Kerdjoudj, H.; Molinari, R.; Seta, P.; Drioli, E. Fixed sites plasticized cellulose triacetate membranes containing crown ethers for silver(I), copper(II) and gold(III) ions transport. J. Membr. Sci. 2004, 228, 149-157. [CrossRef]

33. Kolodziejska, M.; Kozlowska, J.; Kozlowski, C. Separation of silver(I) and copper(II) by polymer inclusion membranes with aza[18]crown-6 derivatives as ion carriers. Desalin. Water Treat. 2017, 64, 432-436. [CrossRef]

34. Shamsipur, M.; Hashemi, O.R.; Lippolis, V. A supported liquid membrane system for simultaneous separation of silver(I) and mercury(II) from dilute feed solutions. J. Membr. Sci. 2006, 282, 322-327. [CrossRef]

35. Ulewicz, M.; Sadowska, K.; Biernat, J.F. Selective transport of $\mathrm{Pb}(\mathrm{II})$ across polymer inclusion membrane using imidazole azocrown ethers as carriers. Physicochem. Probl. Miner. Process. 2007, 41, 133-143.

36. Kolodziejska, M.; Kozlowski, C.; Kozlowska, J.; Ulewicz, M. Selective removal of Ag(I) and Cu(II) by plasticizer membranes with N-(diethylthiophosphoryl)-aza[18]crown-6 as a carrier. Physicochem. Probl. Miner. Process. 2014, 50, 237-247. [CrossRef]

37. Ulewicz, M.; Lesinska, U.; Bochenska, M. Transport of lead polymer inclusion membrane with p-tert-butylcalix[4]arene derivative. Physicochem. Probl. Miner. Process. 2010, 44, 245-256.

38. Kayvani Fard, A.; McKay, G.; Buekenhoudt, A.; Al Sulaiti, H.; Motmans, F.; Khraisheh, M.; Atieh, M. Inorganic membranes: Preparation and application for water treatment and desalination. Materials 2018, 11, 74. [CrossRef]

39. Nghiem, L.D.; Mornane, P.; Potter, I.D.; Perera, J.M.; Cattrall, R.W.; Kolev, S.D. Extraction and transport of metal ions and small organic compounds using polymer inclusion membranes (PIMs). J. Membr. Sci. 2006, 281, 7-41. [CrossRef]

40. Schulze, A.; Went, M.; Prager, M. Membrane functionalization with hyperbranched polymers. Materials 2016, 9, 706. [CrossRef]

41. Radzyminska-Lenarcik, E.; Ulewicz, M. Selective transport of $\mathrm{Cu}(\mathrm{II})$ across a polymer inclusion membrane with 1-alkylimidazole from nitrate solutions. Sep. Sci. Technol. 2012, 47, 1113-1118. [CrossRef]

42. Radzyminska-Lenarcik, E.; Ulewicz, M. The use of the steric effect of the carrier molecule in the polymer inclusion membranes for the separation of cobalt(II), nickel(II), copper(II), and zinc(II) ions. Pol. J. Chem. Technol. $2015,17,51-56$.

43. Ulewicz, M.; Radzyminska-Lenarcik, E. Transport of metal ions across polymer inclusion membrane with 1-alkylimidazole. Physicochem. Probl. Miner. Process. 2011, 46, 119-130.

44. Radzyminska-Lenarcik, E.; Ulewicz, M. The use of 1-alkylimidazoles for selective separation of zinc ions in the transport process across a polymer inclusion membrane. Physicochem. Probl. Miner. Process. 2014, 50, 131-142. [CrossRef]

45. Radzyminska-Lenarcik, E.; Ulewicz, M. Polymer inclusion membranes (PIMs) doped with alkylimidazole and their application in the separation of non-ferrous metal ions. Polymers 2019, 11, 1780. [CrossRef] [PubMed]

46. Radzyminska-Lenarcik, E.; Ulewicz, M. The application of polymer inclusion membranes based on CTA with 1-alkylimidazole for the separation of zinc(II) and manganese(II) ions from aqueous solutions. Polymers 2019, 11, 242. [CrossRef]

47. Ajji, Z.; Ali, A.M. Separation of copper ions from iron ions using PVA-g-(acrylic acid/N-vinyl imidazole) membranes prepared by radiation-induced grafting. J. Hazard. Mat. 2010, 173, 71-74. [CrossRef]

48. Radzyminska-Lenarcik, E.; Ulewicz, M. Application of polymer and supported membranes with 1-alkyl-2methylimidazoles for separation of some transition metal ions. Desalin. Water Treat. 2017, 64, 425-431. [CrossRef]

49. Ulewicz, M.; Radzyminska-Lenarcik, E. Application of supported and polymer membrane with 1-decyl-2methylimidazole for separation of transition metal ions. Physicochem. Probl. Miner. Process. 2012, 48, 91-102.

50. Ulewicz, M.; Radzyminska-Lenarcik, E. Supported liquid (SLM) and polymer inclusion (PIM) membranes pertraction of copper(II) from aqueous nitrate solutions by 1-hexyl-2-methylimidazole. Sep. Sci. Technol. 2012, 47, 1383-1389. [CrossRef]

51. Radzyminska-Lenarcik, E.; Witt, K. The application of membrane extraction in the separation of zinc and cadmium ions. Desalin. Water Treat. 2018, 128, 140-147. [CrossRef]

52. Pernak, J.; Krysinski, J.; Skrzypczak, A. Bakterizide wirkung von iminiumverbindungen. Tenside Surfact. Det. 1987, 24, 276-286.

53. Radzyminska-Lenarcik, E.; Ulewicz, R.; Ulewicz, M. Zinc recovery from model and waste solutions using polymer inclusion membrane (PIMs) with 1-octyl-4-methylimidazole. Desalin. Water Treat. 2018, 102, $211-219$. [CrossRef] 
54. Ulewicz, M.; Radzyminska-Lenarcik, E. Application of polymer and supported membranes with 1-decyl-4methylimidazole for pertraction of transition metal ions. Sep. Sci. Technol. 2014, 49, 1713-1721. [CrossRef]

55. Ulewicz, M.; Szczygelska-Tao, J.; Biernat, J.F. Selectivity of $\mathrm{Pb}(\mathrm{II})$ transport across polymer inclusion membranes doped with imidazole azothiacrown ethers. J. Membr. Sci. 2009, 344, 32-38. [CrossRef]

56. Wolf, J.R.; Strieder, W. Tortuosities for a random fiber bed: Overlapping, parallel cylinders of several radii. J. Membr. Sci. 1990, 49, 103-115. [CrossRef]

57. Tor, A.; Arslan, G.; Muslu, H.; Celikas, A.; Cengeloglu, Y.; Ersoz, M. Facilitated transport of Cr(III) thought polymer inclusion membrane with di(2-ethylhexyl)phosphoric acid (DEHPA). J. Membr. Sci. 2009, 329, 169-174. [CrossRef]

58. Salazar-Alvarez, G.; Bautista-Flores, A.N.; San Miguel, E.R.; Muhammed, M.; Gyves, J. Transport characterization of a PIM system used for the extraction of $\mathrm{Pb}$ (II) using D2EHPA as carrier. J. Membr. Sci. 2005, 250, 247-257. [CrossRef]

59. Arous, O.; Kerdjoudj, H.; Seta, P. Comparison of carrier-facilitated silver(I) and copper(II) ions transport mechanisms in a supported and in a plasticized cellulose triacetate membrane. J. Membr. Sci. 2004, 241, 177-185. [CrossRef]

60. Danesi, P.R. Separation of metal species by supported liquid membranes. Sep. Sci. Technol. 1984, 19, 857-894. [CrossRef]

61. Lenarcik, B.; Ojczenasz, P. The influence of the size and position of the alkyl groups in alkylimidazole molecules on their acid-Base properties. J. Heterocycl. Chem. 2002, 39, 287-290. [CrossRef]

62. Lenarcik, B.; Kierzkowska, A. The influence of alkyl chain length on stability Constants of Zn(II) Complexes with 1-Alkylimidazoles in Aqueous Solutions and their partition between aqueous phase and organic solvent. Solvent Extr. Ion Exch. 2004, 22, 449-471. [CrossRef]

63. Barszcz, B.; Garyszewski, M.; Kulig, J. Potentiometric studies on complexes of silver(I) in solutions. Part I. Ag(I) complexes with imidazole, 1-methylimidazole and 2-methylimidazole in aqueous solutions. Pol. J. Chem. 1985, 59, 121-127.

64. Lenarcik, B.; Kierzkowska, A. The influence of alkyl chain length and steric effect on extraction of zinc(II) complexes with 1-alkyl-2-methylimidazoles. Solvent Extr. Ion Exch. 2006, 24, 433-445. [CrossRef]

65. Ulewicz, M.; Radzyminska-Lenarcik, E. Transport of metal ions across polymer inclusion membrane with 1-alkylimidazole. Physicochem. Probl. Miner. Process. 2015, 51, 447-460. [CrossRef]

66. Radzymińska-Lenarcik, E.; Sulewski, M.; Urbaniak, W. Recovery of zinc from metallurgic waste sludges. Pol. J. Environ. Stud. 2015, 24, 1277-1282. [CrossRef] 